\title{
PENGGUNAAN MULTIMEDIA INTERAKTIF DALAM PEMBELAJARAN BAHASA INGGRIS (STUDI KASUS DI SDN 3 TARUBASAN KLATEN)
}

\author{
Suryanti Galuh Pravitasari ${ }^{1)}$, Muhammad Lutfi Yulianto ${ }^{2)}$ \\ STMIK Sinar Nusantara Surakarta \\ email: ${ }^{1}$ galuh.at.edu@gmail.com; ${ }^{2}$ mlutfiyulianto@gmail.com
}

\begin{abstract}
This research aimed to find out whether the use of interactive multimedia in class contributes significant role in the success of the English teaching and learning process. The object of the study was the third grade students of SDN 3 Tarubasan, Klaten. This study is categorized as a class action research which was carried out in two cicles with five meetings each. It was done in the even semester of 2015/2016. A pre-test was given to the objects of the study to record their initial score before the use of the interactive multimedia was implemented. The mean of the pretest was 68,7 with only 3 Objects of the study meeting the passing grade score of 69. At the end of the first cycle, a post-test was given which resulted in a mean of 70,7. The number of the object of study meeting the passing grade score accelerated As much as 61,5\%. Finally, after the second cycles was done, the mean of the post-test was 82,6 with all objects of the study met the passing grade score. It means that there is an increasing of 11,9 point in the students' achievement from the prior-to the treatment with interactive multimedia tool to the first cycle and 13,9 point from the first to the second cycle. All of the objects of the study have also successfully met the passing grade score. Therefore, it can be concluded that the use of interactive multimedia in the English teaching and learning process is proved to give significant influence to the students' final achievement.
\end{abstract}

Keywords: multimedia, interactive, teaching and learning process

\section{PENDAHULUAN}

Perkembangan dan kemajuan teknologi informasi telah memberikan pengaruh yang sangat signifikan di berbagai bidang. Salah satunya yaitu penggunaan multimedia dalam bidang pendidikan. Multimedia di sini berperan sebagai pengantar atau perantara pesan guru kepada siswa. Hal ini dapat mempermudah penyampaian materi pelajaran sebagaimana yang disampaikan oleh Khusna Dan Sumarsih (2016) yang menyatakan bahwa peningkatan motivasi dan ketuntasan belajar dapat tercapai melalui penggunaan multimedia. Selain itu, Hamalik (2008) juga menyatakan bahwa multimedia lebih banyak membantu siswa belajar daripada guru mengajar. Artinya, siswa menjadi lebih mudah menyerap materi pelajaran melalui multimedia yang digunakan dalam kegiatan pembelajaran.
Alasan lain semakin luasnya penggunaan multimedia sebagai alat bantu atau media pembelajaran adalah dikarenakan multimedia ini mampu menampilkan berbagai informasi secara audio visual dan juga interaktif (Rahayuningrum, 2012). Hal ini menjadikan pembelajaran lebih menarik dan lebih efisien sehingga proses pembelajaran dapat terlaksana dengan lebih mudah, lebih menarik dan dapat meningkatkan minat anak-anak untuk belajar.

Salah satu mata pelajaran yang diberikan kepada anak di Sekolah Dasar adalah Bahasa Inggris. Dengan mengenalkan Bahasa Inggris sejak dini diharapkan anakanak dapat menguasai dan berkomunikasi secara lancar dan benar. Kemampuan untuk berkomunikasi ini sangatlah penting di era globalisasi dan era informasi ini. Dengan 
menguasai Bahasa Inggris, anak akan siap jika tiba-tiba harus berhadapan dengan sesuatu yang menggunakan Bahasa Inggris. Sebagai contoh ketika anak dihadapkan dengan buku-buku bacaan atau referensi yang bahasa pengantarnya adalah Bahasa Inggris. Oleh karena itu, pembelajaran Bahasa Inggris ini harus dapat dilaksanakan dengan semaksimal mungkin dan semenarik mungkin sehingga anak tidak akan mudah kehilangan minat untuk belajar.

Kemudian muncullah berbagai teknologi multimedia yang disusun guna mendukung proses pembejaran Bahasa Inggris. Beberapa penelitian tentang penggunaan multimedia di dalam kelas juga telah dilaksanakan. Hasilnya terbukti cukup efektif dalam mewujudkan ketercapaian kompetensi yang diharapkan. Mardika (2012) menyatakan bahwa multimedia memberi kontribusi yang cukup efektif terhadap ketuntasan belajar siswa kelas V SD yang mana sebanyak 95\% murid berhasil tuntas. Selain itu, Sudarsono (2012: vi) juga membuktikan adanya peningkatan ketuntasan belajar mata pelajaran IPA sebesar $81 \%$ melalui penelitiannya tentang penggunaan multimedia dalam pembelajaran IPA.

Beberapa penilitian di atas dijadikan referensi penulis untuk melakukan kegiatan yang sama dengan obyek penelitiannya adalah siswa-siswi kelas III SD Tarubasan Klaten. Penulis meneliti kontribusi penggunaan multimedia untuk mencapai ketuntasan belajar siswa dalam mata pelajaran Bahasa Inggris.

\section{METODE PENELITIAN}

Metode penelitian berasal dari kata "metode" yang bermakna "cara yang tepat untuk melakukan sesuatu; dan "logos" yan bermakna ilmu atau pengetahuan. Jadi dapat disimpulkan bahwa pengertian metode penelitian adalah cara melakukan sesuatu dengan menggunakan pikiran untuk mencapai suatu tujuan. (Narbuko dan Abu Achmadi, 2001:1)

Dalam penelitian ini, cara atau metode yang dilakukan adalah dengan melaksanakan sebuah tindakan atau perlakuan kepada para subyek penelitian di dalam proses pembelajaran di kelas. Oleh karena itu, penelitian ini tergolong ke dalam jenis Penelitian Tindakan Kelas (PTK). Pengertian dari PTK adalah penelitian praktis yang dimaksudkan untuk memperbaiki pembelajaran di kelas. Penelitian ini merupakan salah satu upaya guru atau praktisi dalam bentuk berbagai kegiatan yang dilakukan untuk memperbaiki dan atau meningkatkan mutu pembelajaran di kelas. Selain itu, Aqib (2007: 13) menyatakan bahwa PTK merupakan suatu pencermatan terhadap kegiatan yang dimunculkan dan terjadi dalam sebuah kelas (Sugiyono, 2010). Di sini ada tiga batasan yang disebutkan yaitu penelitian, tindakan, dan kelas. Oleh karena itu dapat disimpulkan bahwa PTK adalah sebuah kegiatan yang meneliti atau mencermati sebuah treatment tertentu yang dengan sengaja diberikan kepada para peserta didik di dalam kelas.

Penelitian ini dilaksanakan di SD Tarubasan Klaten yang secara khusus mengambil kelas III sebagai subyek dari penelitian ini. Kelas III SD tarubasan ini memiliki 13 murid. Penelitian ini berlangsung pada semester genap 2015/2016. Obyek penelitian adalah penggunaan media ajar berbasis multimedia dalam pembelajaran Bahasa Inggris. Berhubung penelitian ini termasuk dalam kategori Penelitian Tindakan Kelas (PTK), maka dilaksanakan dalam dua siklus. Masing-masing siklus dilaksanakan dalam tiga pertemuan. Di akhir pertemuan dari setiap siklusnya, dilaksanakan sebuah tes untuk mengetahui kemajuan dari proses pembelajaran dengan menggunakan multimedia. Sebelum siklus, penulis juga melaksanakan pre-tes untuk 
mengetahui bekal awal dari masing-masing siswa di kelas III tersebut. Pengumpulan data dalam penelitian ini dilaksanakan dengan teknik observasi, wawancara, catatan lapangan, angket, dan tes.

\section{Metode Pengumpulan Data}

Pengumpulan data dilakukan melalui:

\section{a. Observasi}

Pengamatan atau observasi adalah alat pengumpulan data yang dilakukan dengan cara mengamati dan mencatat secara sistematik gejala-gejala yang diselidiki. (Nurbuko dan Abu Achmadi, 2001: 70). Berdasarkan pengamatan yang dilakukan, diperoleh data bahwa tujuan pembelajaran Bahasa Inggris kelas III SD Tarubasan, yang terwujud dalam nilai rata-rata kelas, belum dapat dikatakan berhasil dicapai. Hal ini disebabkan oleh beberapa faktor yang dapat dikelompokkan ke dalam faktor internal dan eksternal.

Faktor internal adalah faktor yang berasal dari dalam diri para murid kelas III SD Tarubasan tersebut. Faktor-faktor tersebut antara lain adalah tingkat kecerdasan, kurangnya motivasi, dan kurangnya konsentrasi. Hal ini terlihat selama dalam proses pengamatan, banyak sekali murid yang tidak fokus pada pembelajaran. Sebaliknya mereka mngerjakan hal-hal lain misalnya bercakap-cakap, menggambar, dan sebagainya.

Faktor eksternal adalah faktor yang mempengaruhi dari luar atau dari selain yang ada dalam diri murid-murid tersebut. Salah satu faktor eksternal yang mempengaruhi kurang berhasilnya pencapaian tujuan pembelajaran adalah kurangnya media atau bahan ajar yang dapat menarik minat para murid. Pembelajaran berlangsung secara teacher center. Oleh karena itu, para murid kehilangan konsentrasi dengan cepat.

b. Wawancara

Wawancara adalah proses tanya-jawab dalam penelitian yang berlangsung secara lisan dalam mana dua orang atau lebih bertatap muka mendengarkan secara langsung informasi- informasi atau keterangan-keterangan. (Cholid Nurbuko dan Abu Achmadi, 2001: 70). Saat ini, metode wawancara ini sering digunakan dalam penelitian. Hal ini disebabkan tanpa wawancara peneilitian akan kehilangan informasi yang hanya dapat diperoleh dengan bertanya langsung kepada responden.

Hasil yang diperoleh penulis dalam kegiatan wawancara dengan guru Bahasa Inggris kelas III SDN III Tarubasan ini adalah kurangnya sarana dan prasarana untuk membuat proses pembelajaran berjalan lebih menarik. Teknologi informasi yang mendukung proses pembelajaranpun belum ada.

c. Tes

Metode pengumpulan data yang selanjutnya adalah dengan memberikan tes kepada para responden. Tes merupakan suatu teknik atau cara yang digunakan dalam rangka melaksanakan kegiatan pengukuran, yang di dalamnya terdapat berbagai pertanyaan, pernyataan, atau serangkaian tugas yang harus dikerjakan atau dijawab oleh peserta didik untuk mengukur aspek perilaku peserta didik (Arifin, 2012: 118). Tes yang diberikan kepada responden berupa tes sebelum perlakuan atau sebelum penggunaan multimedia dalam pembelajaran Bahasa Inggris dimulai. Hal ini bertujuan untuk mengetahui bekal awal kemampuan dari para responden. Tes yang kedua adalah tes yang diberikan setelah siklus I selesai. Jika hasil dari tes pada siklus I sudah sesuai dengan target penelitian, maka proses perlakuan selesai.

Sebaliknya jika hasil tes pada Siklus I belum menghasilkan prestasi yang memuaskan, maka akan diulang satu siklus lagi (Siklus 2) yang akan diakhir dengan sebuah tes. Hasilnya diharapkan sudah dapat memenuhi tujuan dari penelitian ini.

\section{Definisi Operasional Variabel}

a. Multimedia 
Multimedia adalah penggunaan berbagai media yang berbeda untuk membawa atau menyampaikan informasi dalam bentuk teks, grafik, animasi, audio, video dan atau gabungan dari beberapa komponen tersebut. Multimedia dapat dibagi menjadi dua kategori yaitu multimedia content production dan multimedia communication. Multimedia content production adalah penggunaan dan pemrosesan beberapa media yang berbeda untuk menyampaikan informasi atau menghasilkan produk multimedia. Multimedia communication adalah penggunaan multimedia untuk tujuan komunikasi (Rahayu, 2013: 7).

Multimedia merupakan gabungan dari beberapa media diantaranya:

1) Teks

Teks merupakan dasar dari pengolaan kata dan informasi berbasis multimedia. Dalam kenyataannya, multimedia meyajikan informasi kepada audiens dengan cepat karena tidak diperlukan membaca rinci dan teliti.

2) Gambar

Gambar merupakan segala sesuatu yang diwujudkan secara visual dalam bentuk dan dimensi. Sebagai contoh data mahasiswa dengan atribut seperti nama, alamat, nim, dll. Lebih efektif apabila foto mahasiswa yang bersangkutan ditampilkan.

3) Suara

Suara mampu menjelaskan karakteristik suatu gambar, misalnya music dan suara efek.

4) Grafik

Secara umum grafi berarti gambar garis. Grafik ini merupakan sarana yang baik untuk menyajikan informasi.

5) Animasi

Animasi menggambarkan objek yang bergerak agar kelihatan lebih hidup. Membuat animasi menggerakkan gambar seperti kartun, lukisan, tulisan, dll (Munadi, 2008).

\section{Media Pembelajaran}

Kata "media" merupakan bentuk jamak dari kata"medium" yang berasal dari Bahasa Latin yang berarti "perantara". Pengertian lebih jauh tentang media adalah sesuatu yang membawa informasi dari sumber untuk diteruskan kepada penerima. "Media pembelajaran" diartikan sebagai suatu alat atau bahan yang mengandung informasi atau pesan pembelajaran. Penggunaan media dalam hal ini ditunjukkan untuk memperlancar jalanya komunikasi dalam proses pembelajaran (Marisa, 2011:6).

Berbagai penelitian yang dilakukan terhadap pemanfaatan media pembelajaran meninjukkan bahwa media tersebut berdampak positif dalam pembelajaran. "Sebuah gambar lebih berarti dari seribu kata" seperti dituliskan oleh DePorter, Reardon, dan Singer-Noure (1999) bahwa penggunaan alat peraga dalam mewakili proses belajar akan merangsang modalitas visual dan menyalakan jalur saraf sehingga memunculkan beribu-ribu asosiasi dalam kesadaran sisiwa. Rangsangan visual dan asosiasi ini akan memberikan suasana yang sangat kaya untuk pembelajaran.

Beberapa alasan mengapa media pembelajaran perlu digunakan dalam proses pembelajaran menurut Marisa (2011: 7-9) adalah:

1. Pembelajaran lebih menarik dan interaktif 
Penggunaan media pembelajaran (foto, video) dalam hal ini dapat menarik perhatian siswa bila dibandingkan dengan hanya menjelaskan deskripsi secara lisan.

2. Pembelajaran menjadi lebih kongkret dan nyata.

Penggunaan media pembelajaran di SD, terutama dikelas rendah, sangat sesuai dengan karakteristik siswa yang masih berada dalam taraf 'operasionalkongkret'. Dalam taraf ini siswa lebih mudah mempelajari segala sesuatu yang secara langsung dapat mereka lihat, denganr, pegang dan rasakan.

3. Mempersingkan proses penjelasan materi pembelajaran.

Suatau topik, terlebih bila topic tersebut sulit dijelaskan secara lisan, akan memakan waktu lama. Mengganti cara penjelasan dengan menggunakan media pembelajaran, akan mengurangi waktu yang akan anda gunakan untuk member penjelasan lisan kepada siswa.

4. Mendorong siswa belajar secara lebih mandiri

Media pembelajaran yang sudah dirancang khusus untuk pembelajaran tentu dapat digunakan oleh siswa untuk belajar baik secara individual maupun dalam kelompok.

5. Materi pembelajaran lebih terstandarisasi Bila guru menyampaikan materi pembelajaran menggunakan media tertentu, maka setiap siswa akan mendaoatkan materi pembelajaran yang sama.

6. Belajar dan mengajar dengan memanfaatkan aneka sumber belajar.

Dengan banyaknya informasi yang ada disekitar kita saat ini, baik itu berupa bahan yang tercetak (Koran atau majalah) maupun yang ada dalam bentuk audiovisual (termasuk internet), maka kita sebagai guru dan siswa sebagai individu yang belajar mempunyai sumber belajar yang sangat kaya. Sumber belajar yang ada saat ini, sangat mungkin dimanfaatkan dalam proses belajarmengajar (Marisa, 2011: 7-9).

\section{Teknik Analisis Data}

Penelitian Tindakan bertujuan untuk mengembangkan ketrampilan-ketrampilan atau cara pendekatan baru dan untuk memecahkan masalah dengan penerapan langsung di dunia kerja atau dunia aktual yang lain. (Nurbuko dan Abu Achmadi, 2001: 55). Dalam penelitian ini, tindakan dilakukan di dalam kelas. Oleh karena itu, pengembangan multimedia yang sudah disusun akan diaplikasikan secara langsung dalam proses pembeljaran Bahasa Inggris di kelas III SDN III Tarubasan, Klaten.

Analisis data kualitatif digunakan untuk menentukan peningkatan proses belajar khususnya berbagai tindakan yang dilakukan guru. Analisis data yang dilakukan yaitu mendeskripsikan data yang dilakukan dalam bentuk naratif, membuat grafik atau menyusunnya dalam bentuk tabel. Kemudian penarikan kesimpulan yakni proses penarikan intisari dari sajian data yang telah terorganisir dalam bentuk pernyataan untuk menjawab rumusan masalah.

Data kuantitatif dianalisa dengan teknik analisa sederhana dengan menggunakan prosentase. Analisa data kuantitatif dilaksanakan dengan cara:

1. Kategorisasi Data

Data yang diperoleh disusun berdasarkan kategori tertentu untuk 
memudahkan analisis tes pemahaman (konsep, proses, dan aplikasi konsep).

2. Validasi Data

Agar data bersifat objektif, valid, dan reliabel, maka dalam penelitian ini dilakukan teknik triangulasi dan saturasi yaitu dengan melakukan beberapa tahapan antara lain:

a. Menggunakan cara yang bervariasi untuk mendapatkan data yang sama misalnya dengan tes, pengamatan, dan wawancara.

b. Menggali data yang sama dari sumber yang berbeda. Dalam penilitian ini ada dua sumber yaitu guru dan siswa.

c. Mengecek kelengkapan dan keakuratan data dengan caramelakukan pengecekan ulang.

d. Melakukan pengolahan dan analisa ulang dari data yang sudah terkumpul
3. Intepretasi data

Intepretasi data dilakukan berdasarkan teori dan atauran yang disepakati atau menggunakan intuisi/pengetahuan penulis dan guru untuk menciptakan proses pembeajaran yang menarik sebagai bekal pada tahap pembelajaran.

4. Tindakan

Hasil intepretasi data dapat digunanakan untuk informasi dalam penentuan tindakan selanjutnya.

\section{Rancangan Kegiatan Penelitian}

Sebagaimana yang disampaikan oleh Aqib (2007: 30), PTK dilaksanakan melalui proses pengkajian berdaur yang terdiri dari 4 tahap seperti yang diilustrasikan dalam gambar 1.

Kemudian menurut Hopkins sebagaimana dikutip oleh Aqib (2007:31) pelaksanaan tindakan dalam PTK digambarkan melalui gambar 2 .

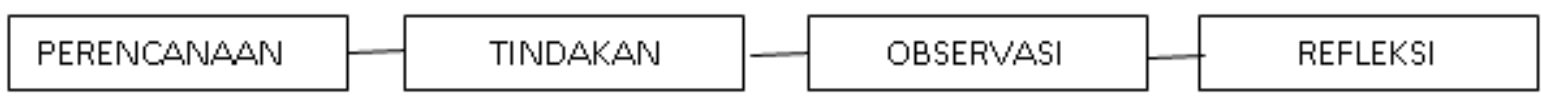

Gambar 1. Prosedur Pelaksanaan PTK

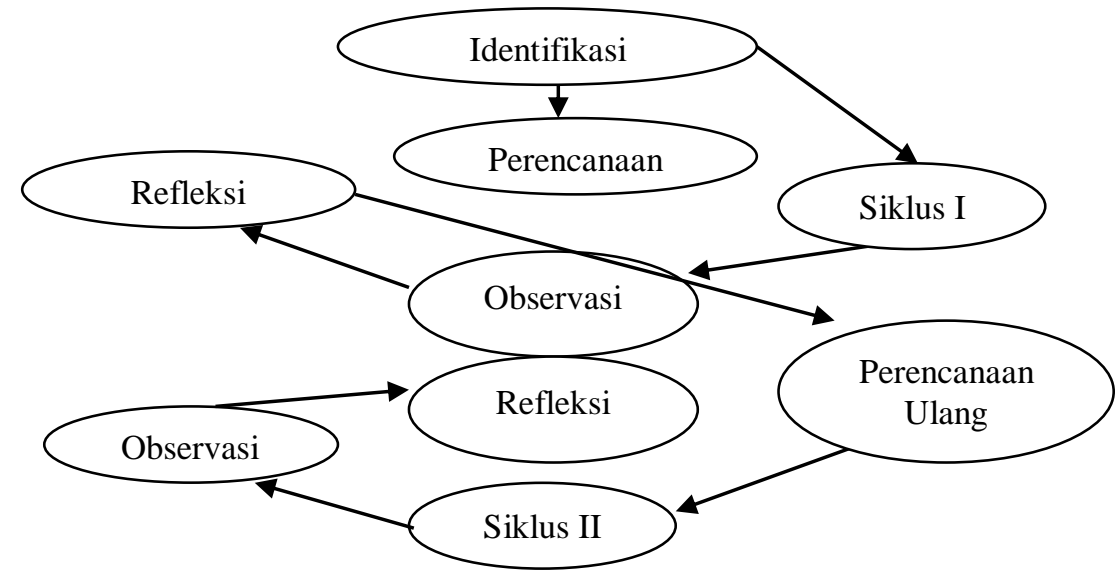

Gambar 2. Spiral Tindakan Kelas (adaptasi dari Hopkins, 1993:48) 
Dalam penelitian ini, penulis melaksanakan dua siklus dimana setiap siklus dilaksanakan dalam 5 tatap muka (sesuai dengan jumlah materi yang harus disampaikan).

Berikut ini adalah tahapan pelaksanaan penelitian yang dilakukan oleh penulis:

\section{Siklus I}

\section{Perencanaan}

Setelah permasalahan teridentifikasi melalui pengamatan dan wawancara, tahap pertama yang dilaksanakan adalah merencanakan kegiatan-kegiatan dan mempersiapkan perangkat-perangkat yang diperlukan dalam proses penelitian. Tahapan ini meliputi:

a. Menyusun Rencana Pembelajaran (RPP)

b. Mempersiapkan materi dan media pembelajaran yang berupa perangkat komputer/laptop dan software multimedia yang akan digunakan

c. Mempersiapkan lembar pengamatan dan daftar nilai

2. Tindakan

Dalam tahap ini, penulis melaksanakan beberapa kegiatan:

a. Kegiatan awal (Pra-pembelajaran) Kegiatan ini meliputi:

1) Membuka pertemuan dengan kegiatan 'brainstorming' sesuai dengan tema

2) Menjelaskan tujuan dan gambaran proses pembelajaran

3) Memberikan pre-test untuk mengetahui bekal awal para subyek penelitian

b. Kegiatan Inti

1) Menjelaskan cara penggunaan media ajar (multimedia)

2) Para subyek peneilitian dipersilakan memulai kegiatan pembelajaran melalui multimedia yang telah disediakan.

3) Peneliti melakukan pendampingan kepada subyek penelitian dalam berinteraksi dengan multimedia yang disediakan

4) Peneliti melaksanakan observasi dan mencatat segala temuan selama proses pembelajaran berlangsung

5) Mencatat hasil post-test siklus I

\section{c. Refleksi}

Pada kegiatan ini, peneliti melakukan analisi data dari hasil pengamatan/observasi ketika proses pembelajaran berlangsung. Selain itu, peneliti juga melaksanakan analisa terhadap hasil pre-test dan post-test pada siklus I. Hasil pre-test menunjukkan bahwa rata-rata nilai yang diperoleh siswa sebelum proses pembelajaran dengan menggunakan multimedia interaktif dilaksanakan adalah 68,5. Sementara itu rata-rata nilai setelah pembelajaran dengan menggunakan multimedia interaktif adalah 70,7. Ini berarti sudah ada peningkatan sebesar 2,2 point. Namun, dikarenakan masih ada beberapa subyek penelitian yang mendapat nilai di bawah KKM yang sebesar 6,9, maka peneliti memutuskan untuk melanjutkan penelitian pada Siklus II.

\section{Siklus II}

a. Perencanaan

Setelah permasalahan teridentifikasi melalui pengamatan dan wawancara, tahap pertama yang dilaksanakan adalah merencanakan kegiatan-kegiatan dan mempersiapkan perangkat-perangkat yang 
diperlukan dalam proses penelitian. Tahapan ini meliputi:

1) Menyusun Rencana Pembelajaran (RPP)

2) Mempersiapkan materi dan media pembelajaran yang berupa perangkat komputer/laptop dan software multimedia yang akan digunakan

3) Mempersiapkan lembar pengamatan dan daftar nilai

b. Tindakan

Dalam tahap ini, penulis melaksanakan beberapa kegiatan:

1) Kegiatan awal (Pra-pembelajaran)

Kegiatan ini meliputi:

- Membuka pertemuan dengan kegiatan 'brainstorming' sesuai dengan tema

- Menjelaskan tujuan dan gambaran proses pembelajaran

2) Kegiatan Inti

- Menjelaskan cara penggunaan media ajar (multimedia)

- Para subyek peneilitian dipersilakan memulai kegiatan pembelajaran melalui multimedia yang telah disediakan.

- Peneliti melakukan pendampingan kepada subyek penelitian dalam berinteraksi dengan multimedia yang disediakan

- Peneliti melaksanakan observasi dan mencatat segala temuan selama proses pembelajaran berlangsung

- Mencatat hasil post-test siklus II

- Refleksi

Pada kegiatan ini, peneliti melakukan analisis data dari hasil pengamatan/observasi ketika proses pembelajaran berlangsung. Selain, peneliti juga melaksanakan analisa terhadap hasil post-test pada Siklus I dan post-test pada siklus II. Hasil posttest menunjukkan bahwa rata-rata nilai yang diperoleh siswa setelah proses pembelajaran dengan menggunakan multimedia interaktif adalah 70,7. Sementara itu rata-rata nilai setelah pembelajaran dengan menggunakan multimedia interaktif pada Siklus II adalah 82,6. Ini berarti sudah ada peningkatan sebesar 11,9 point. Semua subyek penelitian sudah berhasil mendapatkan nilai yang di atas KKM sebesar 69. Oleh karena itu peneliti memutuskan untuk menghentikan penelitian pada Siklus II saja.

\section{HASIL DAN PEMBAHASAN}

Daftar nilai baik yang dari pre-test, posttest pada Siklus I dan post-test pada Siklus II digunakan oleh peneliti untuk mengetahui apakah tujuan dari penelitian tindakan kelas ini tercapai atau tidak.

Hasil pre-test sebelum perlakuan penggunaan multimedia interaktif diberikan kepada para subyek penelitian adalah seperti yang terlihat dalam Tabel 1. Rata-rata perolehan nilai pre-test ketiga belas subyek penelitian adalah 68,5. Angka ini masih di bawah KKM yang sebesar 69. Berdasarkan pengamatan, perolehan angka yang masih di bawah KKM ini dikarenakan subyek belum mendapatkan pembelajaran mengenai materi yang diujikan dalam pre-test. Namun, dengan rata-rata 68,5 tersebut sebenarnya dapat disimpulkan bahwa bekal kemampuan Bahasa Inggris para subyek sudah terbilang cukup bagus. Dalam Tabel 1 tersebut juga terlihat ada sejumlah 3 atau $23 \%$ dari subyek penelitian yang sudah melampaui KKM. Sementara yang lain belum. 
Tabel 1. Hasil Penilaian Pre-test

\begin{tabular}{clcc}
\hline No & Nama Siswa & Nilai & Nilai Rata-rata Kelas \\
\hline 1. & Tio & 68 & \\
2. & Revina & 76 & \\
3. & Bagas & 62 & \\
4. & Juve & 76 & \\
5. & Abi & 68 & \\
6. & Ozy & 60 & \\
7. & Maya & 64 & \\
8. & Hawin & 78 & \\
9. & Aldinatamuti & 62 & \\
10. & Farel & 56 & \\
11. & Azizah & 56 & \\
12. & Rista & 68 & \\
13. & Farhan & 62 & \\
\hline
\end{tabular}

Sebagaimana yang terlihat dalam Tabel $1 \mathrm{di}$ atas, rata-rata perolehan nilai pre-test ketiga belas subyek penelitian adalah 68,5. Angka ini masih di bawah KKM yang sebesar 69 . Berdasarkan pengamatan, perolehan angka yang masih di bawah KKM ini dikarenakan subyek belum mendapatkan pembelajaran mengenai materi yang diujikan dalam pre-test. Namun, dengan rata-rata 68,5 tersebut sebenarnya dapat disimpulkan bahwa bekal kemampuan Bahasa Inggris para subyek sudah terbilang cukup bagus. Dalam Tabel 1 tersebut juga terlihat ada sejumlah 3 atau $23 \%$ dari subyek penelitian yang sudah melampaui KKM. Sementara yang lain belum.

Di akhir Siklus I penulis mengadakan posttest untuk para subyek penelitian. Hasil dari post-test tersebut dapat dilihat dalam Tabel 2.

Tabel 2. Hasil Penilaian Post-Test pada Siklus I

\begin{tabular}{|c|c|c|c|}
\hline No & Nama Siswa & Nilai & Nilai Rata-rata Kelas \\
\hline 1. & Tio & 72 & \\
\hline 2. & Revina & 76 & \\
\hline 3. & Bagas & 60 & \\
\hline 4. & Juve & 76 & \\
\hline 5. & Abi & 72 & \\
\hline 6. & Ozy & 76 & \\
\hline 7. & Maya & 80 & 70,7 \\
\hline 8. & Hawin & 92 & \\
\hline 9. & Aldinatamuti & 68 & \\
\hline 10. & Farel & 56 & \\
\hline 11. & Azizah & 52 & \\
\hline 12. & Rista & 80 & \\
\hline 13. & Farhan & 60 & \\
\hline
\end{tabular}

Tabel 2 memperlihatkan bahwa ada peningkatan nilai rata-rata dari pre-test ke post-test yaitu dari angka 68,5 menjadi 70,7. Ini berarti ada peningkatan sebesar 2,2 point. Jumlah subyek penelitian yang sudah melampaui nilai KKM adalah sebanyak 3 orang atau $23 \%$. Sementara itu, nilai ratarata post-test pada Siklus I, sebagaimana 
dapat dilihat pada tabel 2, adalah sebesar 70,7 dan jumlah subyek yang nilai posttestinya sudah melebih KKM sejumlah 8 orang atau $61,5 \%$ dari total subyek penelitian. Hal ini menunjukkan adanya peningkatan sebesar $28,5 \%$ pada jumlah subyek penelitian yang sudah melampaui
KKM dari sebelum perlakuan/pelaksanaan PTK ke setelah Siklus I selesai diberikan.

Di akhir Siklus II, peneliti mengadakan post-test. Hasilnya seperti terlihat dalam tabel 3 .

Tabel 3. Hasil Penilaian Post-Test pada Siklus II

\begin{tabular}{clcc}
\hline No & \multicolumn{1}{c}{ Nama Siswa } & Nilai & $\begin{array}{c}\text { Nilai Rata-rata } \\
\text { Kelas }\end{array}$ \\
\hline 1. & Tio & 86 & \\
2. & Revina & 93 & \\
3. & Bagas & 78 & \\
4. & Juve & 84 & \\
5. & Abi & 75 & \\
6. & Ozy & 79 & 82,6 \\
7. & Maya & 90 & \\
8. & Hawin & 98 & \\
9. & Aldinatamuti & 76 & \\
10. & Farel & 70 & \\
11. & Azizah & 73 & \\
12. & Rista & 94 & \\
13. & Farhan & 78 & \\
\hline
\end{tabular}

Tabel 3 menunjukkan bahwa nilai rata-rata post-test pada Siklus II meningkat cukup tajam yaitu dari angka 70,7 pada Siklus I ke angka 82,6 pada Siklus II. Hal ini berarti ada peningkatan sebesar 11,9 point. Tabel 3 juga memperlihatkan bahwa seluruh subyek penelitian yang berjumlah 13 anak telah berhasil melampaui nilai KKM. Hal ini menunjukkan adanya peningkatan jumlah subyek penelitian yang telah melampaui KKM sebanyak 38,5\% dari hasil post-test pada Siklus I atau sebesar 77\% jika dibandingkan dengan hasil pre-test.

Jika ditampilkan dalam bentuk grafik, maka perbandingan peningkatan nilai rata-rata dari pre-test, post test Siklus I, dan post test pada Siklus II akan terlihat dalam gambar 4 .

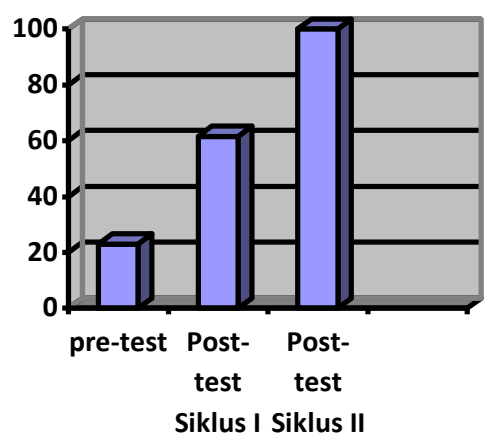

Dumlah Subyek yang

melampaui KKM

Gambar 4. Diagram Perbandingan Jumlah Subyek Yang telah Melampaui KKM 
Berdasarkan data-data di atas, penulis dapat menyimpulkan bahwa penggunaan multimedia interaktif dalam pembelajaran Bahasa Inggris di Kelas III SDN III Tarubasan, Klaten ini terbukti mampu meningkatkan ketuntasan belajar siswa. Oleh karena itu, tujuan dari pelaksanaan Penelitian Tindakan Kelas (PTK) ini berhasil.

\section{SIMPULAN}

Berdasarkan hasil penelitian tindakan kelas yang berjudul "Penggunaan Multimedia Interaktif dalam Pembelajaran Bahasa Inggris Kelas III SDN 3 Tarubasan Klaten" penulis dapat menyimpulkan bahwa penggunaan multimedia interaktif tersebut dapat memberikan pengaruh yang positif terhadap peningkatan ketuntasan dan pemahaman para siswa kelas III SDN 3 Tarubasan. Hal ini dapat dilihat dari adanya peningkatan nilai rata-rata para peserta didik sebelum diberi perlakuan sebesar 68,7 dan setelah diberi perlakuan pembelajaran dengan multimedia interaktif selama 2 siklus yaitu sebesar 82,6. Hal ini berarti ada peningkatan sebesar 13.9 point.

Terdapat peningkatan jumlah peserta didik yang nilainya melampaui batas KKM dari sebelum perlakuan tindakan pembelajran dengan multimedia interaktif yaitu 3 anak menjadi 13 anak atau seluruh peserta didik telah berhasil menuntaskan pembelajaran Bahasa Inggris setelah melalui dua kali siklus. Sehingga total peningkatan jumlah ketuntasan belajar peserta didik adalah $77 \%$.

Hal ini bermakna bahwa penggunaan multimedia interaktif dapat memberikan beberapa manfaat terhadap ketuntasan belajar peserta didik yaitu antara lain:
1. Perubahan model pembelajaran dari teacher centered ke student centered.

2. Keaktifan dan konsentrasi peserta didik dalam proses pembelajaran juga meningkat dikarenakan tampilan desain multimedia interaktif yang bagus.

3. Peserta didik lebih bersemangat dan gembira dalam mengikuti proses pembelajaran dikarenkan peserta didik belajar sambil bermain

\section{Implikasi}

Berdasarkan pengamatan selama proses pembelajaran Bahasa Inggris dengan menggunakan multimedia interaktif, saran yang dapat diberikan oleh penulis adalah:

1. bagi peserta didik:

Pembelajaran dengan menggunakan multimedia interaktif memang sangat menyenangkan, tetapi perlu kiranya sebelum proses pembelajaran dengan multimedia tersebut dimulai, peserta didik diberi kegiatan semacam brainstorming secara lisan oleh guru. Selain brainstorming, sedikit kegiatan fisik misal senam otak juga dapat menajdi alternatif untuk merangsang semangat peserta didik dalam mengikuti proses pembelajaran.

2. Bagi guru

Seiring semakin melajunya perkembangan teknologi, maka disarankan para guru juga mengikuti perkembangan teknologi tersebut dengan banyak mencoba aplikasiaplikasi yang tersedia di internet untuk diunduh dan diaplikasikan ke dalam proses pembelajaran supaya peserta didik dapat belajar dengan lebih menyenangkan.

3. Bagi sekolah 
Kiranya sekolah menyadari betapa penting ketersediaan sarana dan prasaran pembelajaran yang memadai jika ingin memberikan layanan yang terbaik kepada para peserta didiknya. Selain itu, dengan saran dan prasarana yang mencukupi, prestasi akademik dari peserta didik pun akan meningkat. Sehingga perlu kiranya menganggarkan dana untuk membeli perangkat multimedia dan diletakkan di setiap ruang kelas.

\section{DAFTAR PUSTAKA}

Aqib, Zainal (2007). Penelitian Tindakan Kelas: untuk Guru. Yrama Widya, Bandung.

Khusna, Meitiya Sumarsih (2016). Pemanfaatan Media CD Interaktif untuk Meningkatkan Moitivasi dan prestasi Belajar Akuntansi. iJurnal kajian Pendidikan Akuntansi Indonesia, Vol. 5 No.7

Marisa, dkk, 2011. Komputer Dan Media Pembelajaran. Universitas Terbuka

Munadi, Yudhi (2008). Media Pembelajaran: Sebuah Pendekatan. Gaung Persada, Ciputat, Bandung

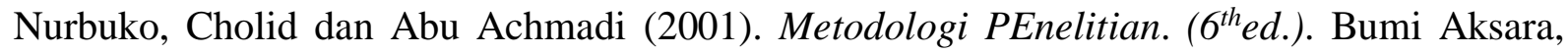
Jakarta

Rahayuningrum, Rosalia Hera. 2012. Penggunaan Media Pembelajaran CD interaktif Berbantuan Komputer untuk meningkatkan motivasi dan Kemampuan Pemecahan Masalah Matematika Siswa kelas VIIF di SMPN 2 Imogiri. Skripsi. digilib.uns.ac.id, Universitas Sebelas Maret Surakarta.

Sudarsono (2012). Penggunaan Multimedia Interaktif untuk meningkatkan Pemahaman Konsep Perubahan Lingkungan Fisik pada Siswa Kelas IV SDN Jimbung, Klaten. Skripsi. digilib.uns.ac.id, Universitas Sebelas Maret Surakarta.

Sugiyono (2010). Metode Penelitian Pendidikan: Pendekatan Kuantitatif, Kualitatif, dan $R \& D$, Alfabeta, Bandung 